\title{
Fluoride distribution in groundwater, soil and some crops grown in fluoride endemic area
}

\author{
D. VIJAYA LAKSHMI, K. JEEVAN RAO, T. RAMPRAKASH AND A.P.K. REDDY
}

Article Chronicle :

Received:

16.08.2016;

Revised:

07.11.2016;

Accepted :

17.11.2016

Key Words : Fluoride, Ground water, Soil, Crops, Nalgonda
ABSTRACT : Fluoride content of ground water, soils and some cereal and vegetable crops were estimated in 26 villages in Aatmakoor mandal of Nalgonda district, Telangana, India. The results indicated that, accumulation of fluoride (F) was observed in different plant parts of crops irrigated with F contaminated ground water ( 0.73 to 3.25 and 1.12 to $4.67 \mathrm{mg} \mathrm{L}^{-1}$ during Kharif and Rabi seasons, respectively) grown in soil containing 0.41 to 2.32 and 0.68 to $2.63 \mathrm{mg} \mathrm{kg}^{-1}$ available fluoride during Kharif and Rabi seasons, respectively. All the values obtained were well below the toxic limit of 2.57 to $6.44 \mathrm{mg} \mathrm{kg}^{-1}$ in soil and maximum contaminant level of $4.0 \mathrm{mg} \mathrm{kg}^{-1}$ in crops and vegetable stipulated by EPA, FAO, and WHO Joint standard limit for fluoride. The implication of the results is that the use of the ground water for irrigation and the contribution of fluoride to the soil and absorption by the crops, has no deleterious effect on the soil and some crops cultivated with ground water. Maximum accumulation of $\mathrm{F}$ ( $\mathrm{mg} \mathrm{kg}^{-1}$ dry wt.) occurred in the roots followed by shoot and economic part. The mean $F$ levels in the economic part of the crops analyzed are follows the order, paddy $>$ sorghum $>$ red gram in Kharif and groundnut > paddy > sorghum in Rabi.

HOW TO CITE THIS ARTICLE : Lakshmi, D. Vijaya, Rao, K. Jeevan, Ramprakash, T. and Reddy, A.P.K. (2016). Fluoride distribution in groundwater, soil and some crops grown in fluoride endemic area. Asian J. Environ. Sci., 11(2): 137-143, DOI: 10.15740/HAS/AJES/11.2/137-143.
Author for correspondence :

\section{VIJAYA LAKSHMI}

Krishi Vigyan Kendra (PJTSAU), Rudrur, NIZAMABAD

(TELANGANA) INDIA

Email : vijjiprabhu888@

gmail.com

See end of the article for

Coopted authors' 